\title{
A FORMAÇÃO DE OBSTETRIZES NO BRASIL: DESAFIO E TRANSFORMAÇÃO
}

Dulce Maria Rosa Gualda ${ }^{1}$

O panorama da saúde materno-infantil no Brasil tem mostrado um quadro crítico. Os índices de mortalidade materna, embora tenham se mantido estáveis nos últimos quinze anos, são ainda, extremamente elevados, sendo cinco a dez vezes maiores que os dos países de alta renda. Este fato aponta para as disparidades regionais do Brasil e a atuação insuficiente do sistema público de saúde. O desafio na redução do alto índice de cesarianas é outro problema que demanda solução no enfrentamento da morbi-mortalidade materna e neonatal. São evidentes as deficiências, tanto quantitativas quanto qualitativas, de recursos humanos para atuar na promoção da saúde sexual e reprodutiva.

Na esfera educacional, os currículos herméticos constituem em desafio, são pautados no modelo biomédico, tendendo para as patologias e para a especialização. Desta forma, distanciam os profissionais da visão humanística e dos aspectos socioeconômicos e culturais da população, dificultando-lhes uma visão crítica da saúde no contexto nacional. Sendo assim, a formação não dá espaço à atividade interdisciplinar, à criatividade e à possibilidade de transformação da realidade, que permitiria colaborar positivamente para alterar os indicadores de saúde das mulheres.

Frente a tais dificuldades, a Organização das Nações Unidas, no ano 2000, lançou as metas do milênio, com prioridade para promover a saúde das gestantes e reduzir a mortalidade infantil até o ano de 2015. No mesmo período, a Organização Mundial de Saúde divulgou as metas para a promoção da Maternidade Segura, destacando a importância da qualificação do acompanhamento profissional durante a gestação, parto e puerpério. Reconhecendo a relevância da formação profissional para a melhoria da qualidade da assistência à mulher, em 2005 foi criado o Curso de Obstetrícia, em nível de graduação, pela Universidade de São Paulo. Neste, o aprendizado é desenvolvido por meio de atividades de ensino, pesquisa e extensão, com vistas a articular a construção de conhecimento como reflexão sobre a realidade social; o compromisso social com o Sistema Único de Saúde e com o cuidado integral em saúde; e, a adoção de modelo de cuidado centrado na mulher e no cumprimento das políticas de humanização da assistência.

Experiências como essa vêm apresentando resultados positivos e podem ser vistas em países desenvolvidos, como Holanda e Inglaterra, nos quais a formação de midwives (obstetrizes) tem contribuído para a qualidade assistencial das mulheres durante todo ciclo gravídico-puerperal. As obstetrizes estão inseridas no sistema de saúde, tanto em equipes multiprofissionais, quanto na atuação autônoma de assistência às mulheres. Entretanto, no Brasil, a sua inserção tem se mostrado dificultosa e árdua, pois ela presume a mudança de paradigma e a competição pelo mercado de trabalho.

Formar obstetrizes não significa deixar de investir na especialização em Enfermagem Obstétrica. Ambos são campos comuns que buscam o mesmo objetivo: a melhoria da assistência à saúde da mulher. O ponto crucial, em ambos, é fortalecer um modelo de atenção que não seja centrado no modelo biomédico, reconhecendo que a atuação da enfermeira obstétrica e da obstetriz são essenciais para a reconfiguração da assistência, o que virá a representar um impacto frente aos desfavoráveis indicadores de saúde materna no Brasil.

Assim, a perspectiva é a de que a obstetriz faça parte das equipes de saúde, juntamente com médicos e enfermeiras obstétricas. A história tem demonstrado que o trabalho conjunto, de diferentes profissionais, apresenta maior capacidade de melhorar os indicadores de saúde reprodutiva.

${ }^{1}$ Enfermeira obstétrica. Doutora em Enfermagem. Professora da Escola de Enfermagem da Universidade de São Paulo. Presidente do Programa Interunidades de Doutoramento em Enfermagem. 


\section{THE FORMATION OF MIDWIVES IN BRAZIL: CHALLENGE AND TRANSFORMATION}

Dulce Maria Rosa Gualda ${ }^{1}$

The panorama of maternal and child health in Brazil is a critical one. The figures for maternal mortality, although stable over the last fifteen years, are still extremely high, being five to ten times higher than in highincome countries. This fact reflects the regional inequalities in Brazil and the inadequate performance of the public health system. The challenge of reducing the high levels of caesareans is another problem in need of a solution in confronting maternal and neonatal morbimortality. The deficiencies in human resources - both quantitative and qualitative - for carrying out sexual and reproductive health promotion are clear.

In the sphere of education, the hidebound curriculums also constitute a challenge. Being based on the biomedical model and inclining towards pathologies and to specialization, they distance health professionals from a humanistic vision and from the socio-economical and cultural characteristics of the population, hindering them from developing a critical understanding of health in a Brazilian context. This being the case, professional formation does not give space to interdisciplinary activity, to creativity and to the possibility of transforming reality, which would permit positive collaboration to alter the health markers for women's health.

Faced with such difficulties, in the year 2000 the United Nations Organisation launched its Millennium Development Goals, which prioritized the promotion of health for expectant mothers and the reduction of infant mortality by the year 2015. During the same period, the World Health Organisation released its goals for Making Pregnancy Safer, highlighting the importance of the qualification of the professional accompaniment during pregnancy, birth and puerperium.

Recognizing the relevance of professional formation in improving the quality of care to women, the University of São Paulo in 2005 created the degree-level Obstetrics Course, in which the learning process is developed through teaching activities, research and short extension courses; this is with a view to constructing knowledge as a reflection of social reality, of the social pledge with the National Health Service and with integral health care, and of the adoption of a model of care centered on women's health needs and on fulfilling the policies of humanization of care.

Experiments such as this present positive results and may be seen in developed countries such as Holland and the United Kingdom, where formation of midwives has contributed to the quality of care that women receive during the pregnancy-puerperal cycle. Midwives are integral to the health system, both in health teams and in autonomous roles in women's health care. Meanwhile in Brazil the same placing has proven problematic and arduous, as it assumes a paradigm shift and competition for the job market.

Producing midwives does not mean stopping investing in specialization in obstetric nursing. Both camps seek the same goal: improvement in women's healthcare. The crucial point in both is strengthening a model of care which rather than centering on the biomedical model recognizes that the roles of obstetric nurses and midwives are essential to the reconfiguration of care, which will come to represent an impact on the unfavourable health markers associated with maternal health in Brazil.

Thus the perspective is that the midwife should become part of health teams, along with doctors and obstetric nurses. History has demonstrated that team work involving different professions presents a better capacity for improving health markers in reproductive health.

${ }^{1}$ Obstetric nurse. PhD in Nursing. Professor of the University of São Paulo School of Nursing. President of the Interunit PhD in Nursing Program.

Cogitare Enferm. 2011 Jul/Set; 16(3):407-9 


\section{LA FORMACIÓN DE OBSTETRICES EN BRASIL: DESAFÍO Y TRANSFORMACIÓN}

Dulce Maria Rosa Gualda ${ }^{1}$

El panorama de la salud materno-infantil en Brasil presenta hoy un cuadro crítico. Los índices de mortalidad materna, a pesar de estables en los últimos quince años, todavía son extremamente elevados, siendo cinco a diez veces mayores que los de los países de alta renta. Este hecho apunta para las disparidades regionales de Brasil así como para la actuación insuficiente del sistema público de salud. El desafío en la reducción del alto índice de operaciones cesáreas es otro problema que demanda solución en el afrontamiento de la morbi-mortalidad materna y neonatal. Las deficiencias, tanto cuantitativas cuanto cualitativas, de recursos humanos para actuar en la promoción de la salud sexual y reprodutiva son evidentes.

En la esfera educacional, los currículos herméticos constituyen desafío, pues siguen el modelo biomédico y presentan tendencia a las patologías y a la especialización. De este modo, establecen distancia entre los profesionales de visión humanística y los aspectos socioeconómicos y culturales de la población, dificultando una visión crítica de la salud en el contexto nacional. Así, la formación estorba la actividad interdisciplinar, la creatividad y la posibilidad de transformación de la realidad, lo que podría colaborar positivamente para alterar los indicadores de salud de las mujeres.

Delante de esas dificultades, la Organización de las Naciones Unidas, en año 2000, divulgó las metas del milenio, con prioridad para promover la salud de las gestantes y reducir la mortalidad infantil hasta el año de 2015. En el mismo período, la Organización Mundial de Salud divulgó las metas para la promoción de la Maternidad Segura, destacando la importancia de la cualificación del acompañamiento profesional durante la gestación, parto y puerperio.

Reconociendo la relevancia de la formación profesional a fin de mejorar la cualidade de la asistencia a la mujer, en 2005 fue creado el Curso de Obstetricia, en nivel de graduación, por la Universidad de São Paulo. En este curso, el aprendizaje es desarrollado por medio de actividades de enseñanza, investigación y extensión, con fines de articular la construcción de conocimiento como reflexión sobre la realidad social; el compromiso social con el Sistema Único de Salud y con el cuidado integral en salud; y, la adopción de modelo de cuidado centrado en la mujer y en el cumplimiento de las políticas de humanización de la asistencia.

Experiencias como esa presentan resultados positivos y pueden ser observadas en países desarrollados, como Holanda e Inglaterra, en los cuales la formación de midwives (obstetrices) viene constribuyendo para la cualidad asistencial de las mujeres durante todo ciclo gravídico-puerperal. Las obstetrices están en el sistema de salud, tanto en equipos multiprofesionales, cuanto en la actuación autónoma de asistencia a las mujeres. Sin embargo, en Brasil, su inserción se muestra dificil y árdua, pues ella presupone un cambio de paradigma y la competición por el mercado de trabajo.

Formar obstetrices no significa dejar de invertir en la especialización en Enfermería Obstétrica. Ambas son áreas comunes que tienen el mismo objetivo: mejorar la asistencia a la salud de la mujer. El punto crucial, en ambos, es fortalecer un modelo de atención que no sea centrado en el modelo biomédico, reconociendo que la actuación de la enfermera obstétrica y de la obstetriz son esenciales para la reconfiguración de la asistencia, lo que representará un impacto delante de los desfavorables indicadores de salud materna en Brasil.

Así, la perspectiva es la de que la obstetriz integre los equipos de salud, junto a los médicos y enfermeros obstétricos. La historia viene demostrando que el trabajo conjunto, de diferentes profesionales, presenta mayor capacidad de mejorar los indicadores de salud reproductiva.

Enfermera obstétrica. Doctora en Enfermería. Profesora de la Escuela de Enfermería de la Universidad de São Paulo. Presidente del Programa

"Interunidades de Doutoramento em Enfermagem". 